\title{
Transdermal Nitroglycerin Enhances Lidocaine And Neostigmine for Intravenous Anesthesia in Patients Undergoing Hand Surgery. A Prospective Randomized Double Blind Placebo Control Study.
}

\author{
Osama Farouk**, Jamal Shahin **, Hassan Abudaleh*, Mohammed Abdelkawy*, \\ and Amr Mokhtar** \\ *From the Department of Anesthesia and the Department of Orthopedics \\ **King Abdulaziz Naval Base Hospital, Jubail, KSA.
}

\begin{abstract}
In a prospective randomized blind study, we investigated the effects of adding transdermal nitroglycerine for lidocaine and neostigmine for intravenous regional anesthesia in adult patients undergoing hand surgery.
\end{abstract}

\section{Patients and Methods}

Sixty patients (ASA grade I, aged 20-60 years) of both sexes were enrolled. The patients were randomly allocated to receive either $40 \mathrm{ml}$ of $0.5 \%$ lidocaine plus a transdermal placebo patch (control group $\mathrm{n}=15$ ), $40 \mathrm{ml}$ of $0.5 \%$ lidocaine with $0.5 \mathrm{mg}$ of neostigmine plus a transdermal placebo patch (Neostigmine group, $\mathrm{n}=15$ ), $40 \mathrm{ml}$ of $0.8 \%$ lidocaine plus a transdermal nitroglycerine patch (Nitroglycerine group, $\mathrm{n}=15$ ) or $40 \mathrm{ml}$ of $0.5 \%$ lidocaine with $0.5 \mathrm{mg}$ of neostigmine plus a transdermal nitroglycerine patch (Neostigmine - Nitroglycerine group, $\mathrm{n}=15$ ). All routine hemodynamic parameters and $\mathrm{O} 2$ saturation were monitored, surgical time, sensory and motor block onset times, sensory and motor block recovery times and time to first analgesic requirement were measured. Operative conditions and quality of anesthesia were also recorded.

\section{$\underline{\text { Results }}$}

Sensory and motor block onset times were shorter in the neostigmine - nitroglycerine group compared with all other groups $(\mathrm{p}<0.05)$. Sensory block recovery time was significantly prolonged and the quality of anesthesia was better in the neostigmine - nitroglycerine group compared with all other groups $(\mathrm{p}<0.05)$.

\section{Conclusion}

We found that the addition of $0.5 \mathrm{mg}$ neostigmine to $40 \mathrm{ml}$ of $0.5 \%$ lidocaine for intravenous regional anesthesia with a $5 \mathrm{mg}$ transdermal nitroglycerine patch improved the operating conditions and quality of anesthesia and prolonged postoperative relief with no adverse effects.

\section{Introduction}

Intravenous regional anesthesia (IVRA) is a technically simple and reliable form of regional anesthesia for short procedures on the extremities, with success rates of $94-$ $98 \%{ }^{(3)}$. It is also associated with a more favorable patient recovery profile than general anesthesia ${ }^{(4)}$. However, it has been limited by tourniquet pain, delayed onset of action, poor muscle relaxation, inability provide post - operative analgesia, and lack of bloodless field ${ }^{(8)}$. These limitations might be avoided by the addition of various adjuncts to the local anesthetics including morphine, fentanyl, sufentanil, clonidine, atracurium, neostigmine and nonsteroidal anti - inflammatory drugs ${ }^{(6)}$.

Previously, an interest had focused on the cholinergic system that modulates pain perception and transmission. It was shown that the spinal or epidural administration of 
the acetylcholine esterase inhibitor neostigmine results in a dose dependent analgesia by inhibition of the breakdown of acetylcholine (ACH) in the spinal cord ${ }^{(13)}$. There are $\mathrm{ACH}$ receptors in the peripheral nerves ${ }^{(7)}$, and when neostigmine was added as an adjunct to prilocaine during IVRA, the quality of anesthesia was improved, with prolonged post operative analgesia ${ }^{(19)}$. Data from the literature suggest that in human, high dose nitroglycerine are hyperalgesic, whereas doses less than $6 \mathrm{mg}$ per day are analgesic under different circumstances ${ }^{(13)}$. Moreover, transdermal nitroglycerine was found to enhance spinal sufentanil post operative analgesia following orthopedic surgery (16), and it prolonged the analgesic effect of intrathecal neostigmine ${ }^{(13)}$.

The aim of the study was to determine the possible clinical advantage of application of transdermal nitroglycerine patch in patients undergoing hand surgery with IVRA using a combination of lidocaine and neostigmine.

\section{Patients and Methods}

This study took place in King Abdulaziz Naval Base Hospital, Jubail, KSA from November 2008 to January 2010. The study was approved by the Hospital ethics Committee. After obtaining written informed consent, 60 ASA physical status I adult patients aged between 20-60 years, of both sexes, undergoing hand surgery were enrolled. Patients who were scheduled to undergo surgery that was anticipated to last more than 90 min., those with Raynaud's disease, sickle cell anemia, the use of analgesics within the last 24 hours before the study, or history of allergy to any drug used, were excluded from participation.

All patients were premedicated with $0.07 \mathrm{mg} \mathrm{kg}^{-1}$ of midazolam and $0.01 \mathrm{mg} \mathrm{kg}^{-1}$ atropine given intramuscularly $45 \mathrm{~min}$. before the surgical procedure. A transdermal therapeutic system (transdermal patch) was applied to all patients at the ventral side of the upper forearm; 2 hours before the start of IVRA, and containing either nitroglycerine $5 \mathrm{mg}$ (a nitric oxide generator) or a placebo according to the assigned group.

A standard technique was used in all patients. A 20-gauge cannula was inserted in a vein on the dorsum of the operative hand. Another cannula was inserted in a vein on the other arm. Patients were monitored for mean arterial blood pressure (MAP), oxygen saturation $\left(\mathrm{SPO}_{2}\right)$ and heart rate (HR) in the operating room. A padded tourniquet positioned around the upper arm. The injured arm was elevated for $2 \mathrm{~min}$. then exanguinated using an Esmarch band which was wrapped around the whole limb distal to the upper arm tourniquet except the hand region. The tourniquet was then inflated to $100 \mathrm{mmHg}$ above the patient's systolic blood pressure, and the Esmarch band was removed. Circulatory isolation of the arm was verified by inspection, absence of radial pulse, and loss of pulse oximetry tracing in the ipsilateral index finger, then the local anesthetic solution was injected over 2 min.

A second tourniquet was then positioned and inflated on the anesthetized part of the arm, followed by removal of the original one.

The patients were randomized to 4 groups with 15 patients each:

Group 1: Receiving 40ml of $0.5 \%$ lidocaine plus a transdermal placebo patch (control group).

Group 2: Receiving $40 \mathrm{ml}$ of $0.5 \%$ lidocaine with $0.5 \mathrm{mg}$ of neostigmine plus a transdermal placebo patch (Neostigmine group).

Group 3: Receiving $40 \mathrm{ml}$ of $0.5 \%$ lidocaine plus a transdermal nitroglycerine patch (Nitroglycerine group).

Group 4: Receiving $40 \% \mathrm{ml}$ of $0.5 \%$ lidocaine with $0.5 \mathrm{mg}$ of neostigmine plus a transdermal nitroglycerine patch (Neostigmine - Nitroglycerine group).

A randomization list was generated and identical syringes and transdermal patches were prepared by an assistant not involved in the study. The surgeon was unaware of the group to which the patient had been allocated.

Onset of sensory block was tested by the surgeon using the pinprick method at 3 separate areas, representing the dermatomal 
sensory distribution of the 3 main nerves of the hand, and anesthesia was declared when there was no sensation. Complete motor block was recorded when no voluntary movement of the fingers was possible. The sensory and motor block onset times were noted as the time elapsed from injection of the study drug to complete sensory and motor blocks respectively. The time between the start and the end of surgery (surgical time) was also noted. MAP, HR, $\mathrm{SPO}_{2}$ were monitored before and after tourniquet application, 5, 10, 15, 20, and 40 min after the injection of anesthetic solution, and after release of the tourniquet by an anesthesia resident who did not know the medication given.

During surgery, the surgeon assessed the degree of muscle relaxation, the ease of reduction and the dryness of the operative field. This was on

a $0-10 \mathrm{~cm}$ visual analogue scale (VAS); where the zero point indicates none, and the 10 indicates good operative conditions. At the end of operation, the anesthetist was asked to qualify the anesthetic conditions. At the end of operation, the anesthetist was asked to qualify the anesthetic conditions according to the following scale:

Excellent (4) $=$ no complaint from the patient.

Good $(3)=$ minor complaint with no need for supplemental analgesics.

Moderate (2) $=$ complaint which required supplemental analgesics.

Unsuccessful (1) = General anesthesia was given.

Deflation of the tourniquet was performed by cyclic deflation technique (not before 30 min had been elapsed from injection of the anesthetic solution) and the transdermal patch was removed $2 \mathrm{~h}$ later. Sensory recovery time was noted (time elapsed after tourniquet deflation, up to recovery of pain in all dermatomes determined by pin prick test). Motor block recovery time was also noted (the time elapsed after tourniquet deflation up to movement of the fingers).

The patients were free to request rescue analgesics after tourniquet deflation and the first analgesic requirement time was noted (the time elapsed after tourniquet release to the first patient request for analgesics). An anesthesia resident (not involved in the study) was always available to administer the analgesic (ketorolac 30mg IM.) when it was requested and pain was assessed by VAS at the time of first analgesic requirement. The patients were also monitored for the occurrence of unwanted effects as nausea, vomiting, bradycardia, central venous system side effects or skin rash after the release of tourniquet and up to $24 \mathrm{~h}$ postoperative in the ward and a suitable management was carried out if necessary.

Statistical analysis was performed using student's t test and chi-square test. P value $<0.05$ was considered significant.

\section{Results}

All 60 patients completed the study. There were no significant differences in patients characteristic (table1). The surgical time was similar in the 4 groups indicating similar operative conditions. Sensory and motor block onset times were statistically shorter in the neostigmine - nitroglycerine group compared with all the other groups $(p<0.05)$, and they were shorter in the neostigmine group compared with the control group $(\mathrm{p}<0.05)$. Patients in the neostigmine - nitroglycerine group had a significantly prolonged sensory block recovery time compared with all other groups $(\mathrm{p}<0.05)$. The motor block recovery time was similar in the neostigmine and the neostigmine - nitroglycerine groups ( $>0.05$ ), but it was prolonged in these 2 groups compared to the control group $(\mathrm{p}<0.05)$ (table 2).

The VAS values of the operative conditions; assessed by the surgeon, were similar in the neostigmine and the neostigmine - nitroglycerine groups and these were statistically better in those groups compared to the control group. The quality of anesthesia determined by the anesthesiologist was significantly better in the neostigmine - nitroglycerine group compared to all other groups $(\mathrm{p}<0.005)$ (table 3). Three patients from the control group, one patient from the neostigmine 
group and another two patients in the nitroglycerine group believed that they received poor anesthesia. Midazolam (2.5$5 \mathrm{mg}$ ) and propofol (50-100mg) were used for sedation as required. These results however, were statistically insignificant.

There was no statistical difference between groups when compared for MAP, $\mathrm{SPO}_{2}$ and $\mathrm{HR}$ at any time of measurement $(p>0.05)$. The first analgesic requirement time was longer for the neostigmine nitroglycerine group compared with all other groups $(p<0.005)$, and it was longer for the neostigmine group compared with the control group $(\mathrm{p}<0.05)$. The pain VAS at the time of first rescue analgesic medication was similar among the 4 groups (table 4).

No significant adverse effects were seen in this study either intraoperatively or throughout the $24 \mathrm{~h}$ postoperative period in any group, although 2 patients in the nitroglycerine group and only one patient in the neostigmine group had nausea that required treatment, but this did not reach statistical significance $(\mathrm{p}>0.05)$.

Table (1): patients'characteristics.

\begin{tabular}{|l|l|c|c|c|c|}
\hline & $\begin{array}{l}\text { Control } \\
\text { Group } \\
(\mathbf{n = 1 5})\end{array}$ & $\begin{array}{l}\text { Nitroglycerine } \\
\text { Group (n=15) }\end{array}$ & $\begin{array}{l}\text { Neostigmine } \\
\text { Group (n=15) }\end{array}$ & $\begin{array}{l}\text { Neostigmine } \\
\text { Nitroglycerine } \\
\text { Group (n=15) }\end{array}$ \\
\cline { 2 - 6 } & Age (yrs) & $37(20.3)$ & $28(13.7)$ & $42(22.3)$ & $39(17.7)$ \\
\cline { 2 - 6 } $\begin{array}{l}\text { Sex } \\
\text { (M:F) }\end{array}$ & $8: 7$ & $7: 8$ & $9: 6$ & $8: 7$ \\
\cline { 2 - 6 } $\begin{array}{l}\text { Weight } \\
\text { (Kg) }\end{array}$ & $67(13.2)$ & $65(11.4)$ & $77(17.5)$ & $69(16.7)$ \\
\hline $\begin{array}{l}\text { Height } \\
(\mathrm{cm})\end{array}$ & $168(10.3)$ & $164(10.8)$ & $173(8.7)$ & $166(11.2)$ \\
\hline
\end{tabular}

Data are meaning (SD)

Table (2): Surgical time, onset and recovery times of sensory and motor blocks (min).

\begin{tabular}{|l|c|c|c|c|}
\hline & $\begin{array}{l}\text { Control } \\
\text { Group } \\
(\mathbf{n = 1 5})\end{array}$ & $\begin{array}{l}\text { Nitroglycerine } \\
\text { Group (n=15) }\end{array}$ & $\begin{array}{l}\text { Neostigmine } \\
\text { Group (n=15) }\end{array}$ & $\begin{array}{l}\text { Neostigmine } \\
\text { Nitroglycerine } \\
\text { Group (n=15) }\end{array}$ \\
\hline Surgical Time & $46(13.7)$ & $40(8.9)$ & $44(9.3)$ & $41(8.7)$ \\
\hline $\begin{array}{l}\text { Sensory Block } \\
\text { Onset Time }\end{array}$ & $10.5(1.7)$ & $10(2.1)$ & $4.5(2.3)^{*}$ & $2(1.8)^{+}$ \\
\hline $\begin{array}{l}\text { Sensory Block } \\
\text { Recovery Time }\end{array}$ & $9(1)$ & $6(1)$ & $18(2)^{*}$ & $45(3.3)^{+}$ \\
\hline $\begin{array}{l}\text { Motor Block } \\
\text { Onset Time }\end{array}$ & $13(2)$ & $14(1)$ & $5(2)^{*}$ & $3(2)^{+}$ \\
\hline $\begin{array}{l}\text { Motor Block } \\
\text { Recovery Time }\end{array}$ & $6(1)$ & $3(1)$ & $21(2)^{*}$ & $24(2)^{*}$ \\
\hline
\end{tabular}

Values are mean (SD)

$* \mathrm{p}<0.05$ when compared with control group.

$+\mathrm{p}<0.05$ when compared with all groups. 
Table (3): VAS for operative conditions and the quality of anesthesia.

\begin{tabular}{|l|l|l|l|l|c|}
\hline & & $\begin{array}{l}\text { Control } \\
\text { Group } \\
(\mathbf{n = 1 5})\end{array}$ & $\begin{array}{l}\text { Nitroglycerine } \\
\text { Group } \\
(\mathbf{n = 1 5})\end{array}$ & $\begin{array}{l}\text { Neostigmine } \\
\text { Group (n=15) }\end{array}$ & $\begin{array}{l}\text { Neostigmine } \\
\text { Nitroglycerine } \\
\text { Group (n=15) }\end{array}$ \\
\cline { 2 - 6 } & $\begin{array}{l}\text { VAS of } \\
\text { Operative } \\
\text { Condition }\end{array}$ & $4(0-7)$ & $3.5(0-7)$ & $7.5(4-10)^{*}$ & $9(4-10)^{*}$ \\
\cline { 2 - 6 } & $\begin{array}{l}\text { Quality of } \\
\text { Anesthesia }\end{array}$ & $3(2-4)$ & $3(2-4)$ & $3(2-4)$ & $4(3-4)^{+}$ \\
\hline
\end{tabular}

Values are mean (Range)

$\mathrm{p}<0.05$ when compared with the control group.

$+p<0.05$ when compared with all groups.

Table (4): Time to first analgesic requirement (min)

\begin{tabular}{|l|l|l|l|l|}
\hline & $\begin{array}{l}\text { Control } \\
\text { Group } \\
(\mathbf{n = 1 5})\end{array}$ & $\begin{array}{l}\text { Nitroglycerine } \\
\text { Group } \\
(\mathbf{n = 1 5})\end{array}$ & $\begin{array}{l}\text { Neostigmine } \\
\text { Group } \\
(\mathbf{n = 1 5})\end{array}$ & $\begin{array}{l}\text { Neostigmine } \\
\text { Nitroglycerine } \\
\text { Group } \\
(\mathbf{n = 1 5})\end{array}$ \\
\hline $\begin{array}{l}\text { Time to First Analgesic } \\
\text { Requirement (min) }\end{array}$ & $22(7-80)$ & $20(2-56)$ & $49(15-130)^{*}$ & $106(26-210)^{+}$ \\
\hline $\begin{array}{l}\text { VAS at First Analgesic } \\
\text { Requirement }\end{array}$ & $4.2(4-10)$ & $4.7(4-9)$ & $4.3(4-9)$ & $4(4-8)$ \\
\hline
\end{tabular}

Values are median (Range)

$* p<0.05$ when compared with the control group

$+p<0.05$ when compared with all groups.

\section{Discussion}

The results indicate that the addition of $0.5 \mathrm{mg}$ neostigmine to $40 \mathrm{ml}$ of $0.5 \%$ lidocaine for IVRA, plus a $5 \mathrm{mg}$ transdermal nitroglycerine patch improved the operating conditions and the quality of anesthesia, and prolonged the time to first analgesic requirement. Our results are similar to previous studies that demonstrated the peripheral analgesic effect of neostigmine. Turan et al, had found that the addition of neostigmine to prilocaine in IVRA, shortened sensory and motor block onset times and prolonged the time to first analgesic requirement ${ }^{(19)}$. Yang et al concluded the intra-articular injection of neostigmine after knee arthroscopy produced a significant analgesic effect ${ }^{(24)}$.
Existing $\mathrm{ACH}$ receptors in peripheral nerves are responsible for the action of neostigmine in peripheral analgesia, and $\mathrm{ACH}$ plays a role in the sensory regulatory mechanisms controlled by the motor system ${ }^{(5)}$. Moreover, Varas et al had demonstrated the presence of $\mathrm{ACH}$ receptors in the soma of many petrosal ganglion neurons, thus supporting the idea that under normal conditions, peripheral sensory processes may be associated with $\mathrm{ACH}^{(12)}$.

Our results also showed that $5 \mathrm{mg}$ transdermal nitroglycerine patch (which releases approximately 250 micrograms of nitroglycerine per hour) alone did not result in postoperative analgesia, but the transdermal nitroglycerine parch enhanced the neostigmine analgesic effect. Their 
combination resulted in improved operative conditions with better quality of anesthesia and prolonged postoperative analgesia. The transdermal patch was applied on the operative arm $2 \mathrm{~h}$ before the start of IVRA as the plasma concentration of nitroglycerine reaches a plateau within $2 \mathrm{~h}$ and maintained all through the application period $^{(9)}$.

How nitroglycerine would enhance neostigmine analgesic effect is not known, and some explanations are possible. Several studies had demonstrated the synergistic interaction between nitroglycerine and the mu-opioid receptor agonists. Nitroglycerine was found to enhance morphine after intravenous or spinal administration (23). In addition, systemic morphine increased spinal cord nitric oxide metabolite concentrations, and behavioral analgesia in healthy animals from systemic morphine is blocked by nitric oxide synthetase inhibitors (2). Thus, because of the similarities in the different pain - modulating systems (opioid, $\alpha 2$ adrenergic and cholinergic receptors) (22), we could assume a similar synergistic interaction between nitroglycerine and the muscarinic agents peripherally, nitric oxide produces neither nociceptive nor antinociceptive effects on the receptors ${ }^{(17)}$. However, it modulates the anti inflammatory process and edema formation. Its vasodilator action on the venous system decreases the vasoconstrictor tone induced by the inflammatory process and further reduces the edema formation ${ }^{(2)}$.

Finally, nitroglycerine may have an analgesic effect through the direct stimulation of peripheral fibers mimicking the actions of locally applied $\mathrm{ACH}{ }^{(7)}$.

Therefore, the most probable explanation of our findings is the administration of the acetylcholine esterase inhibitor neostigmine might cause an analgesic effect by increasing endogenous $\mathrm{ACH}$ levels at the peripheral nociceptors. Because of its chemical structure, neostigmine might display longer stability (24), there by insuring a longer analgesic effect. Thus it might enhance the availability of more
$\mathrm{ACH}$ at the assumed peripherally distributed $\mathrm{ACH}$ receptors.

Putative mechanisms of a peripheral cholinergic - mediated antinociception at the peripheral nerve endings are the hyperpolarization of neurons ${ }^{(20)}$, the reduction of pronociceptive neurotransmitter, and the activation of the nitric oxide-cyclic guanosine monophosphate (GMP) pathway (11). In addition, Durate et al previously demonstrated that $\mathrm{ACH}$ induces analgesia via increasing cyclic GMP by generation of nitric oxide (7). Therefore, application of transdermal nitroglycerine patch (a nitric oxide donor) could enhance the neostigmine analgesic effect.

No adverse effects were seen in this study. No evidence of central nervous system side effects or cardiac arrhythmias was seen after local anesthetic administration, before and during surgery and after release of the tourniquet. This could be due to the relatively long operative time in all patients (more than $40 \mathrm{~min}$ ) and the deflation of tourniquet by the cyclic deflation technique. The small dose of neostigmine used and the patient's premedication with atropine may have a role in preventing unwanted neostigmine effects.

In conclusion, we found that the addition of $0.5 \mathrm{mg}$ neostigmine to $40 \mathrm{ml}$ of $0.5 \%$ lidocaine for IVRA with a $5 \mathrm{mg}$ transdermal nitroglycerine patch, improved the operating conditions and quality of anesthesia, and prolonged postoperative pain relief, with no adverse effects. Therefore, this technique is worth further investigations to determine the effect in different peripheral blocks.

\section{References}

(1)Berrasueta JR, Fleitas M, Salas E, et al. (1994): Local transdermal glyceryl trinitrate has an anti inflammatory action on thrombophlebitis induced by sclerosis of leg varicose veins. Angiology; 45:347-51.

(2)Bouaziz H, Tong CY, Yoon Y, et al. (1996): Intravenous opioids stimulate norepinephrine and acetylcholine release in spinal cord dorsal horn-systematic studies in sheep and an 
observation in a human. Anesthesiology; 84:143-54.

(3)Chan VWS, Weisbrod MJ, Kaszas Z, Dragomir C (1999): Comparison of ropivacaine and lidocaine for intravenous regional anesthesia in volunteers. Anesthesiology,90: 1602-8.

(4)Chan VWS, Peng PWH, Kaszas Z, et al. (2001): A comparative study of general anesthesia, intravenous regional anesthesia, and axillary block for outpatient hand surgery: clinical outcome and cost analysis. Anesth Analg, 93: 1181-4.

(5)Chiou-Tan FY, Chou GC (2000): Contribution of circulating acetylcholine to sensory nerve conduction augmentation. Life SCI; 66:1509-18.

(6)Choyce A, Peng P (2002): A systemic review of adjuncts for intravenous regional anesthesia for surgical procedures. Can J Anaesth, 49:3245.

(7)Durate IDG, Lorenzetti BB, Ferreira SH (1990): Peripheral analgesia and activation of the nitric oxide-cyclic GMP pathway. Eur J pharmacol; 186:289(23)Durate IDC, Lorenzetti BB, Ferreira SH (1999): Acetylcholine enduces peripheral analgesia by the release of nitric oxide, nitric oxide from L-Argenin. A Bioregulatory system. Edited by S Moncada, EA Higgs.Amsterdam,Elsevier; 165-70.-93.

(8)El-Hakim M, Sadek RA (1994): Addition of atracurium to lidocaine for intravenous regional anesthesia. Acta Anaesthesiol Scand, 38:542-4.

(9)Feelisch M, Nouck EA (1987): Correlation between nitric oxide formation during degradation of organic nitrates and activation of guanylate cyclase. Eur J pharmacol; 139:19-30. (10)Hood DD, Eisenach JC, Tong C, et al. (1995): Cardiorespiratory and spinal cord blood flow effects of intrathecal neostigmine sulfate, clonidine, and their combination in sheep. Anesthesiology, 82:428-35.

(11)Iwamato ET, Marion L (1994): Pharmacological evidence that spinal muscarinic analgesia is mediated by an Larginine / nitric oxide / cyclic GMP cascade in rats. J pharmacol Exp Ther; 271:601-8.

(12)Kleinschmidt S, Stock LW, Wilhelm W, Larsen R (1997): The addition of clonidine to prilocaine for intravenous regional anesthesia. Eur J Anaesthesiol, 14:40-6.

(13)Lauretti GR, Lima IC (1996): The effects of intrathecal neostigmine on somatic and visceral pain: Improvement by association with a peripheral anticholinergic. Anesth Analg, 82:617-20.

(14)Lauretti GR, Azevedo VMS (1996): Intravenous ketamine or fentanyl prolongs postoperative analgesia after intrathecal neostigmine. Anesth Analg, 83:766-70.

(15)Lauretti GR, Oliveria AM, Juliao MC, et al. (2000): Transdermal nitroglycerine enhances spinal neostigmine postoperative analgesia following gynecological sugery. Anesthesiology, 93: 943-6.

(16)Lauretti GR, Oliveira R, Reis MP, et al. (1999): Transdermal nitroglycerine enhances spinal sufentanil postoperative analgesia following orthopedic surgery. Anesthesiology, 92:134-9.

(17)Mahsimo T, Pak M, Choe H, et al (1997): Effects of vasodilators guanethidine, nicardine, nitroglycerine, and prostaglandin E1on primary afferent nociceptors in human. J Clin pharmacol, 37:330-5.

(18)Reuben SS, Steinberg RB, Lurie SD, Gibson CS (1999): A dose - response study of intravenous regional anesthesia with meperidine. Anesth Analg, 88:831-5.

(19)Turan A, Karaman Lyoglu B, Memis D, et al (2002): Intravenous regional anesthesia using prilocaine and neostigmine. Anesth Analg, 95: 1419-22.

(20)Urban L, Willets J, Murasek (1989): Cholinergic effects on spinal dorsal horn neurons in vitro: an intracellular study. Brain Res; 500:12-20.

(21)Varas R, Alcayaga J, Zapata P (2000): Acetylcholine sensitivity in sensory neurons dissociated from the cat petrosal ganglion. Brain Res; 882:201-5.

(22)Yaksh TL, Jage J, Takano Y (1993): The spinal actions of alpha adrenergic agonists as analgesics. Baillieres clin Anesthesiol; 7:597614.

(23)Yamagushi H, Naito H (1996): Antinociceptive synergistic interaction between morphine and n-nitro L-arginine methyl = Ester on thermal nociceptive tests in the rats. Can $\mathbf{J}$ Anaesth; 43(9):75-81.

(24)Yang LC, Chen LM, Wang CJ, Buerkle H (1998): Postoperative analgesia by intraarticular neostigmine in patients undergoing knee arthroscopy anesthesiology; 88:334-9. 


\title{
إعطاء التيتروجلسرين عن طريث لصقه جلايه يعزز تأثثر التخدير

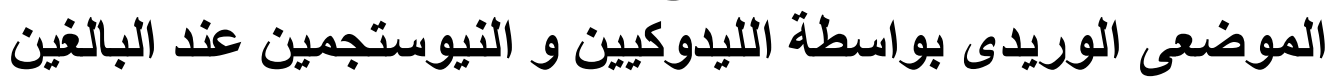

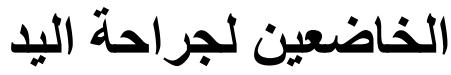

\author{
در اسه عثو ائيه \\ د/ اسامه فاروق, د/ جمال شاهين,د/ حسن ابو دله, د/ محمد عبد القوى, و د/ عمرو مختار
}

من خلال در اسه عشو ائيه في مستشفى قاعدة الملك عبد العزيز البحرية ,الجبيل,المملكة العربية السعودية , إنية تم اكتشاف تأثير إضافة النيتروجلسرين عن طريث لصقيه جلديه على استعمال الليدوكيين و النيوستجمين كخدر موضعى عند البالغين الخاضعين لجر احة اليد.

تم أخذ عينه من البالغين تتر اوح أعمار هم بين • ب ـ • . سنه و تصنيفهم بالدرجه الأولى حسب الجمعيه الأمريكيه للتخدير و تقسيمهم الى ع مجمو عات.

المجوعه الأولى أعطيت ·ـ مللتر من الليدوكيين بتركيز 0, • ٪ مع لصقه جلديه و هيه. المجموعه الثانيه أعطيت •ـ مللتر من الليدوكيين بتركيز 0, • ٪ و نصف ملجر ام نيوستجمين مع لصقه جلديه و هميه.

المجموعه الثالثه أعطيت • ع مللتر من الليدوكيين بتركيز ^, • ٪ مع لصقه جلديه من النيتروجلسرين. المجموعه الرابعه أعطيت · ع مللتر من الليدوكيين بتركيز 0, • ٪ و نصف ملجر ام نيوستجمين مع لصقه جلديه من النيتروجلسرين.

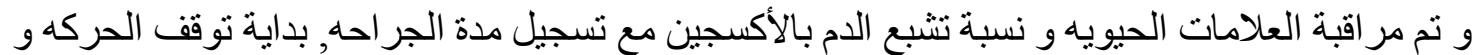

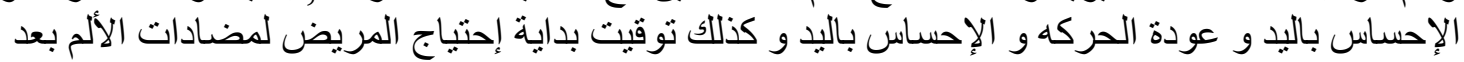
العمليه وكذلك مدى جودة التخدير أثناء العمليه.

تبين من خلال الدر اسه أن بدية فقدان الحركهو الإحساس باليد (التخدير) كان اسرع و عودة الاحساس بعد فتره أطول و كفائة التخدير فى المجمو عله الر ابعه.

فى النهايه تبين ان إضافة نصف ملجر ام نيوستجمين الى • ع مللتر من الليدوكيين بتركيز 0, • ٪ للتخدير

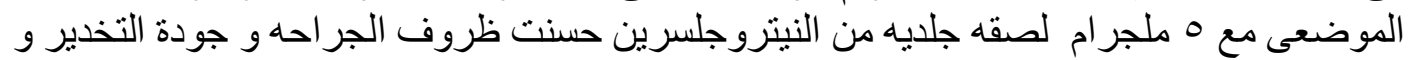
اطالت فترة الإحتياج لمضادت الألم بعد العمليه و بلون النيت أثنار جانبيه. 